\title{
Price and Income Elasticities of Gasoline Demand in Iran: Using Static, ECM, and Dynamic Models in Short, Intermediate, and Long Run
}

\author{
Vahid Mohamad Taghvaee, Parviz Hajiani \\ Economics Department, Persian Gulf University, Bushehr, Iran \\ Email:vahidestan@yahoo.com, hajiani@pgu.ac.ir
}

Received 26 June 2014; revised 20 July 2014; accepted 30 July 2014

Copyright (C) 2014 by authors and Scientific Research Publishing Inc.

This work is licensed under the Creative Commons Attribution International License (CC BY). http://creativecommons.org/licenses/by/4.0/

(c) (i) Open Access

\section{Abstract}

Price and income elasticities of gasoline demand show whether the price policy, pursued by the Iranian government, can decrease the high gasoline consumption sufficiently or not. Since the two oil price shocks in 1970 and 1973, interest in the study of oil products demand has increased considerably, especially on gasoline. High gasoline consumption is a serious crisis in Iran, posing economically, politically, and environmentally threats. In this study, the elasticities are estimated over three intervals, short run, intermediate run, and long run in Iran during 1976-2010, by putting the estimates of Error Correction Model (ECM), static model, and dynamic model in an increasing order, respectively. The short run, intermediate run, and long run price elasticities are $-0.1538,-0.1618$, and -0.3612 and the corresponding income elasticities are $0.2273-0.3581$, 0.4636, and 0.7284, respectively. Not only do these elasticities imply that the gasoline demand is price and income inelastic but also the adjustment velocity, estimated by ECM, is a low point at -0.1942. Based on the estimations, the gasoline demand responds to the changes of price and income slightly and slowly. Therefore, policy makers should develop more strategies to reduce gasoline consumption, for example, substitute goods, public transportation systems, and environmental standards settings.

\section{Keywords}

Gasoline Demand, Price Elasticity, Income Elasticity, Static Model, ECM, Dynamic Model 


\section{Introduction}

Since the two oil price shocks in 1970 and 1973, interest in the study of oil products demand has increased considerably, especially on gasoline [1] [2]. These studies assessed the economical, environmental, and political impacts by evaluating the key elements of gasoline demand. Despite deeply concerning of oil producing countries with the international oil products demand, they pay little attention to the domestic demand of the products [3]. For example, gasoline consumption is a serious crisis in Iran which increased considerably until 2006 [4], causing great threats. The consumption of gasoline, as a subsidized good, is very high in Iran because of the low price which is determined by the government [5].

High gasoline consumption is a serious crisis in Iran, posing economically, politically, and environmentally threats [6]. The gasoline consumption has outnumbered the production level leading to import gasoline. Not only the decreasing balance of payments, economically, but also increasing energy dependency, politically, has threatened the country. As a negative externality, it has resulted in environmental pollution, reducing social welfare [5]. These threats have raised the concerns with the high gasoline consumption.

Due to the great threats, policy makers have planned some strategies to turn down the consumption. For example, Iranian government has forced up the gasoline price noticeably by removing the subsidy in 2007 [6]. The policy can reduce the consumption but it is not clear whether it is effective enough in the reduction or ineffective.

The main objective of this paper is to evaluate the price and income elasticities of gasoline demand in Iran. It shows whether the price policy, pursued by the Iranian government, can decrease the gasoline consumption sufficiently or not. If the gasoline consumption responds insufficiently to the price policy, the governors should choose other alternatives. So estimating price and income elasticities of gasoline demand paves the way to make the right decision.

\section{Literature Review}

There is a large number of studies on gasoline demand with different methods. Table 1 displays different studies and surveys on price and income elasticities of gasoline demand. In three different decades, Dahl (2012), Dahl and Sterner (1991), and Espey (1998) have categorized the important studies, according to the models and estimates [7]-[9]. So a review of the surveys improves an outlook on the subject, before dealing with studies in details.

Table 1. Previous studies and surveys on price and income elasticities of gasoline demand.

\begin{tabular}{|c|c|c|c|c|c|c|}
\hline \multirow{3}{*}{ Study/Survey } & \multirow[t]{3}{*}{ Country } & \multirow[t]{3}{*}{ Model } & \multicolumn{4}{|c|}{ Elasticity } \\
\hline & & & \multicolumn{2}{|c|}{ Price } & \multicolumn{2}{|c|}{ Income } \\
\hline & & & $\mathrm{SR}^{\mathrm{a}}$ & $\mathrm{LR}^{\mathrm{a}}$ & SR & LR \\
\hline Ahmadian et al. (2007) & Iran & Structural time series & -0.19 & -0.74 & 0.32 & 1.25 \\
\hline Akinboade et al. (2008) & South Africa & ARDL & \multicolumn{2}{|c|}{-0.47} & \multicolumn{2}{|c|}{0.36} \\
\hline Baranzini (2013) & Switzerland & $\begin{array}{l}\text { Cointegrating equation and } \\
\text { ECM }\end{array}$ & -0.33 & -0.09 & 0.67 & 0.02 \\
\hline Dahl (2012) & Survey: classificatic & arious countries elasticities & \multicolumn{2}{|c|}{$-0.22^{\mathrm{b}}$} & \multicolumn{2}{|c|}{$0.96^{\mathrm{b}}$} \\
\hline Dahl and Sterner (1991) & \multicolumn{2}{|c|}{ Survey: classification of various studies models } & $-0.26^{\mathrm{b}}$ & $-0.86^{\mathrm{b}}$ & $0.48^{\mathrm{b}}$ & $1.21^{\mathrm{b}}$ \\
\hline $\begin{array}{l}\text { Eltony and Al-Mutairi } \\
\text { (1995) }\end{array}$ & Kuwait & $\begin{array}{l}\text { Cointegrating equation and } \\
\text { ECM }\end{array}$ & -0.37 & -0.46 & 0.47 & 0.92 \\
\hline Espey (1998) & \multicolumn{2}{|c|}{ Survey: classification of various countries elasticities } & $-0.26^{\mathrm{b}}$ & $-0.58^{\mathrm{b}}$ & $0.47^{\mathrm{b}}$ & $0.88^{\mathrm{b}}$ \\
\hline Ramanathan (1999) & India & $\begin{array}{l}\text { Cointegrating equation and } \\
\text { ECM }\end{array}$ & -0.21 & -0.32 & 1.18 & 2.68 \\
\hline Sene (2012) & Senegal & Log linear & -0.12 & -0.30 & 0.45 & 1.13 \\
\hline Wadud et al. (2009) & USA & Cointegration & $-0.08^{\mathrm{b}}$ & $-0.11^{\mathrm{b}}$ & $0.49^{\mathrm{b}}$ & $0.58^{\mathrm{b}}$ \\
\hline
\end{tabular}

${ }^{\mathrm{a}}$ Short-Run (SR) and Long-Run (LR); ${ }^{\mathrm{b}}$ Averagely. 
Dahl and Sterner (1991) have reviewed 97 studies on gasoline demand, the most recent one published in 1988. Despite using different estimation methods, all of the studies have estimated real price and real income as explanatory variables. Due to the vastly various models in the studies, they broke the models into ten "distinct groups" which show nearly unique results. They claim that gasoline demand is mostly inelastic with respect to price and income. Moreover, they argue that correlating the first model with the second models of the ten groups resulted in intermediate run elasticities [8]. There are more recent reviews like this survey.

Espey (1998) has surveyed 101 studies on gasoline demand, made within 1966-1997 with data period from 1929 to 1993 . According to the survey, functional forms and countries are very different but all of them use real price and real income as explanatory variables. Due to the vast range of elasticities in the previous studies, he classified the short run and long run estimates into several groups [9]. Likewise, Dahl (2012) has classified the gasoline demand price and income elasticities of the previous studies with static models into many groups [7]. Overall, the most frequent elasticities imply that gasoline demand is maily inelastic with respect to price and income both in Espey (1998) and in Dahl (2012) [7] [9]. Meta-analyses, like Dahl (2012), Dahl and Sterner (1991), and Espey (1998), deal with the issue as a whole [7]-[9].

There are many surveys which cover the literature generally but reviewing some studies expresses a more detailed attitude of developed countries. Baranzini and Weber (2013) have estimated the price and income elasticities of gasoline demand in Switzerland, employing cointegrating equation and Error Correction Model (ECM). They showed that it is inelastic with respect to both price and income, over the short run and long run. The adjustment velocity is low, at -0.27 , meaning a slow rate of adjustment to the long run equilibrium [10]. Wadud et al. (2009) have obtained the elasticities in USA with cointegration technique. They are inelastic too, just like the last study [11].

Sene (2012), Akinboade et al. (2008), and Ramanathan (1999) concentrated on some developing countries [5] [12] [13]. Sene (2012) has estimated short run and long run price and income elasticities in Senegal, using log linear model. He found that the gasoline demand is inelastic because oil products do not have close substitutes [12]. Akinboade et al. (2008) estimated price and income elasticities of gasoline demand with Autoregressive Distributed Lag Model (ARDL) in South Africa. They showed that the gasoline demand is inelastic in the countries [14]. Ramanathan (1999) has employed cointegrating equation and Error Correction Model (ECM) to estimate the elasticities of gasoline demand in India through two intervals, short run and long run, as well as the adjustment velocity. Although the estimated gasoline demand is income elastic, it is price inelastic in both the spans. The adjustment velocity is low, at 28\%, around that of Baranzini and Weber (2013) [10] [13]. Eltony and Al-Mutairi (1995) have argued that gasoline demand is price and income inelastic in Kuwait, as a developing and oil producing country [15].

Some studies focus on oil producing countries like Iran which is in gasoline consumption crisis [6]. Ahmadian et al. (2007) have claimed that the gasoline consumption is evidently high in Iran, caused by the low price of gasoline, which reduces the social welfare [5].

\section{Models}

The elasticities are estimated over three intervals, short run, intermediate run, and long run in Iran during 19762010, putting the estimates of Error Correction Model (ECM), static model, and dynamic model in an increasing order, respectively. Cointegration technique is used for estimation of the static model and then Error Correction Model (ECM) is employed to estimate the "adjustment velocity" [16]. After the dynamic model estimation, the results of the three models are compared with each other in order to derive the elasticities over the three intervals [8].

\subsection{Static Model}

According to the previous studies, a static model [8], also referred to as "log linear model" [10], with cointegration technique [13] is employed to measure the price and income elasticities of gasoline demand which is as follows:

$$
\operatorname{LnG}_{t}=\alpha_{0}+\alpha_{1} \operatorname{Ln} P_{t}+\alpha_{2} \operatorname{Ln} Y_{t}+u_{t}
$$

where $\operatorname{Ln}$ is the natural logarithm, $G$ is the gasoline demand, $P$ is the real gasoline price, $Y$ is the income, $u$ is the residual term with usual classical characteristics $u_{t} \sim N I D\left(0, \sigma_{u}\right)$ [17], and $t$ is year. Furthermore, $\alpha_{0}$ is in- 
tercept, $\alpha_{1}$ is the long run price elasticity, and $\alpha_{2}$ is the long run income elasticity.

On the basis of Engel-Granger (1987) approach, a cointegrating regression signalizes a long run relationship among variables. Providing that all variables of a regression have the same integration degree of $\rho$, it will be a cointegrating regression if the residual series have a less integration degree than $\rho$ [18]. In this case, parameter $\alpha_{1}$ in Equation (1) is interpreted as the price elasticity of gasoline demand and $\alpha_{2}$ the income elasticity [16].

\subsection{Error Correction Model (ECM)}

Error Correction Model (ECM) is used for the estimation of short run elasticities of gasoline demand [13] [16] which is as follows:

$$
\Delta \operatorname{Ln} G_{t}=\beta_{0}+\beta_{1} \Delta \operatorname{Ln} P_{t}+\beta_{2} \Delta \operatorname{Ln} Y_{t}+\beta_{3} \hat{u}_{t-1}+e_{t}
$$

where $\Delta$ is one degree differentiation, $\hat{u}$ is the estimated residuals in the cointegrating regression, $e$ is the residual term, $\beta_{0}$ is intercept, and the remaining symbols were explained in the previous model. The variables with one degree of integration are stationary by differentiating once. Hence, the regression shows the short run relationship among the variables as parameter $\beta_{1}$ is the gasoline price elasticity of gasoline demand and $\beta_{2}$ is the income elasticity. Also, the coefficient $\beta_{3}$ is the adjustment velocity [16].

\subsection{Dynamic Model}

A dynamic model, referred to as "the partial adjustment model" and "the lagged endogenous model" [8], is employed to verify the results of the static model. In this way, the elasticities of gasoline demand are estimated over the three intervals. The dynamic model is as follows:

$$
\operatorname{LnG}_{t}=\theta_{0}+\theta_{1} \operatorname{Ln} P_{t}+\theta_{2} \operatorname{Ln} Y_{t}+\theta_{3} \operatorname{Ln} G_{t-1}+\varepsilon_{t}
$$

where $G_{t-1}$ is the lagged gasoline demand, $\varepsilon$ is the residual term, $\theta_{0}$ is intercept, $\theta_{1}$ is the short run price elasticity, $\theta_{2}$ is the short run income elasticity, and $\theta_{3}$ is the lagged gasoline demand coefficient. In this model, the long run price and income elasticities are equal to $\frac{\theta_{1}}{1-\theta_{3}}$ and $\frac{\theta_{2}}{1-\theta_{3}}$, respectively [3] [12].

\subsection{Correlating the Estimations}

Putting the estimates of Error Correction Model (ECM), static model, and dynamic models in an increasing order, price and income elasticities of gasoline demand are estimated over three intervals, short run, intermediate run, and long run in Iran during 1976-2010, respectively. The elasticities, estimated by the static model, will be interpreted as the intermediate elasticities, if they wax and wane between the short run and long run elasticities, estimated by the dynamic model [8].

\section{Data}

In this study, dataset includes annual time series data from 1976 to 2010. It is derived from the economic time series database of the Economic Research and Policy Department of $\operatorname{Iran}^{1}$ (see Appendix 1) [4]. Only nominal gasoline price is from the National Iranian Oil Refining and Distribution Company ${ }^{2}$ (see Appendix 2) [19] which is divided by consumer price index $(2004=100)$ so that the inflation is captured. The explanatory variable is per capita gasoline consumption and the dependent variables are real gasoline price and real per capita GDP. The real per capita GDP, as a proxy for income, is GDP at current prices in Rials of Iran, divided by the consumer price index and total population. The per capita gasoline consumption, as a proxy for gasoline demand, is gasoline consumption divided by the total population. It is measured in thousand barrels per day in the database but it is converted to liters per day ${ }^{3}$ because the nominal gasoline price is the value of per liter in Rials of Iran.

Figure 1 reveals some information about how many liters of gasoline are consumed each day in Iran within

\footnotetext{
${ }^{1}$ A department in the Central Bank of the Islamic Republic of Iran. Available from: http://tsd.cbi.ir/

${ }^{2}$ It is in Persian, translated by us. Available from: http://niordc.ir/uploads/fasle11.pdf

${ }^{3}$ On the basis of the International System of Units (IS) a barrel equals 158.98729 liters [20].
} 


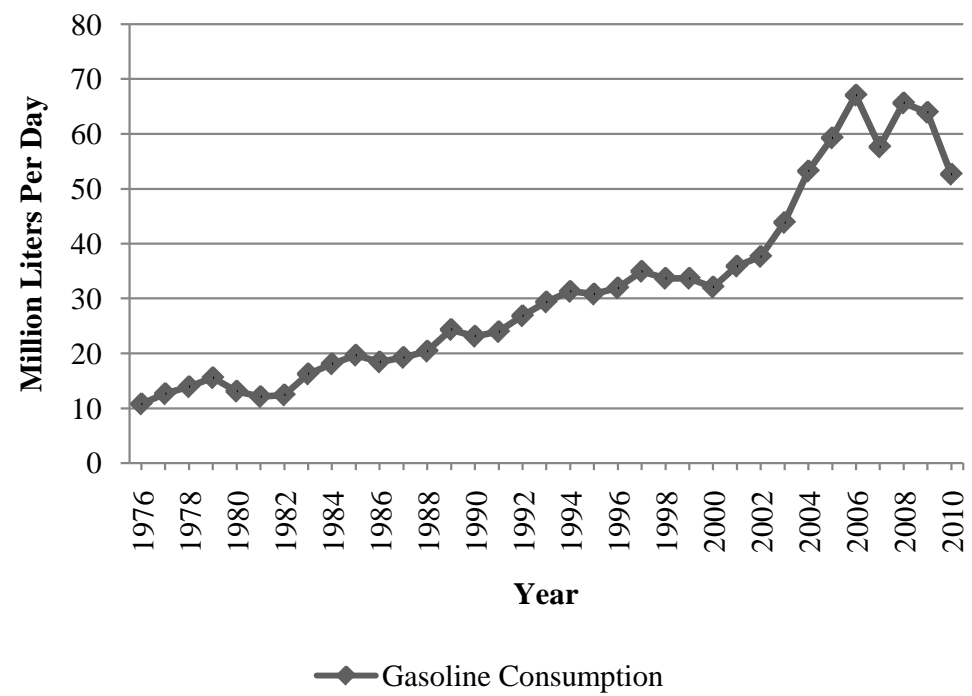

Figure 1. Gasoline consumption in million liters per day in Iran during 19762010 [4].

more than three decades, from 1976 to 2010 (see Appendix 3) [4].

Based on the graph, the gasoline consumption moved upward during 1976-2006. Until 2002, it surged up markedly, reaching well below 40 million, quadrupling the figure in the first year. Since then, the rate of increasing accelerated within the next four years, as the gasoline consumption topped just below 70 million in 2006.

The gasoline consumption rose and fell erratically within the last four years of the span. It collapsed abruptly from in 2007 which comprised about 60 million. Although it recovered to around 65 million in 2008, it took a nosedive in the last two years which accounted for slightly over 50 million in 2010.

In summary, the gasoline consumption in Iran represents an increasing pattern from 1976 to 2010, with some fluctuations in the last four years.

Since the government paid a massive subsidy for gasoline (reaching 10.2 billion US\$ in 2006), its price was low, leading to the high consumption. The high cost of subsidy payment caused the government to formulate some strategies to reduce the consumption, for example, making price policy, setting a higher environmental standard for cars, supplying an alternative fuel (CNG), and gasoline rationing [6]. These led the consumption to fall marginally within 2007-2010, except for 2008.

\section{Results}

Using the Augmented Dickey Fuller (ADF) unit root test, the variables are checked for stationary properties and cointegration relationship. Using Ordinary Least Squares (OLS), the cointegrating equation is regressed to estimate the price and income elasticities. Then the short run and long run elasticities are estimated by the ECM and dynamic model. The static model estimations are interpreted as the intermediate run elasticities because they are between the short run and the long run elasticities. The econometric software package Eviews version 7 and Microsoft Office Excel version 2007 are applied for the estimation.

\subsection{Unit Root Test}

Table 2 shows the results of the ADF tests with intercept. The estimates do not reject the null hypothesis of nonstationarity at $1 \%$ significance level but all the variables are stationary after differentiating once ${ }^{4}$. So they are integrated of the same degree, representing the evidence of cointegration.

\subsection{Static Model}

Table 3 displays the coefficients and the t-statistics of the static model which is a cointegrating regression as a

${ }^{4}$ Whether including a deterministic trend and intercept or not, the results are the same. 
Table 2. Augmented Dickey Fuller (ADF) test statistics for levels and first differentiations of the variables, including intercept $^{\mathrm{a}}$, from 1976 to 2010.

\begin{tabular}{ccc}
\hline Variables & Levels & First differences \\
\hline Ln G & -1.1233 & $-4.6579^{\mathrm{b}}$ \\
Ln P & -1.6676 & $-4.5200^{\mathrm{b}}$ \\
Ln GDP & -0.6434 & $-4.0625^{\mathrm{b}}$ \\
\hline
\end{tabular}

${ }^{\mathrm{a}}$ The results are the same, whether including intercept and trend or not; ${ }^{\mathrm{b}}$ Significant at $1 \%$ level.

Table 3. Results of the static model.

\begin{tabular}{|c|c|c|c|}
\hline Variables & Coefficient & t-statistic & Prob. \\
\hline Ln P & -0.1618 & -3.2406 & 0.0029 \\
\hline Ln GDP & 0.4636 & 3.1758 & 0.0034 \\
\hline Constant & -5.7784 & -3.2878 & 0.0026 \\
\hline $\operatorname{AR}(1)$ & 0.7855 & 8.2553 & 0.0000 \\
\hline Jarque Bera statistic & 0.8680 & & \\
\hline Durbin Watson statistic & 2.0205 & & \\
\hline $\begin{array}{l}\text { Breusch Godfrey serial correlation LM test } \\
\text { (F statistic), including two lags }\end{array}$ & 0.1352 & & \\
\hline $\begin{array}{l}\text { Breusch-Pagan-Godfrey heterroskedasticity test } \\
\text { (F statistic) }\end{array}$ & 2.5071 & & \\
\hline Unit root test statistic of the residual (ADF) & -5.6940 & & \\
\hline R squared & 0.9292 & & \\
\hline Adjusted R squared & 0.9221 & & \\
\hline F statistic & 131.3557 & & \\
\hline Ln P & -0.1618 & & \\
\hline
\end{tabular}

${ }^{\mathrm{a}}$ The results will be the same, if it includes more lags.

long run relationship.

Based on the estimates, the elasticities are low. The price and income elasticities of gasoline demand are -0.1618 and 0.4636 (statistically significant at $1 \%$ level). Not only are the coefficients signs consistent with the economic theories but also the different econometric tests on the residual series confirming the results. They show that the residual satisfies the classical assumptions with Jarque-Bera statistic, Breusch Godfrey serial correlation LM test, and Breusch-Pagan-Godfrey heteroskedasticity test, nevertheless, autocorrelation problem will exist if the regression excludes AR(1). Moreover, the residual is stationary in level, proving the long run relationship. The coefficients of determination and F statistic impress the great accuracy of the regression.

So the model implies reliably that the gasoline demand is inelastic with respect to price and income. Also, lagged residual is used in ECM to estimate the adjustment velocity.

\subsection{Error Correction Model}

Table 4 presents the short run relationship among the variables and the adjustment velocity, using ECM.

In accordance with the table, the elasticities are even lower than those of the static model and the adjustment speed is relatively slow. The short run price and income elasticities of gasoline demand are -0.1538 and 0.2273 . The coefficient of the lagged residuals is -0.1942 which is interpreted as the adjustment velocity. Just like the static model, the coefficients signs are in alignment with the economic theory and the residual of the regression satisfies the classical assumptions. As the coefficients of determination and F statistic are high, the regression is perfectly fit. 
Overall, the model represents an inelastic gasoline demand in the short run with low adjustment speed.

\subsection{Dynamic Model}

Table 5 illustrates the coefficients and the t-statistics of the dynamic model.

Table 4. Results of the Error Correction Model (ECM).

\begin{tabular}{cccc}
\hline Variables & Coefficient & t-statistic & Prob. \\
\hline$\Delta$ Ln P & -0.1538 & -3.1718 & 0.0036 \\
$\Delta$ Ln GDP & 0.2273 & 1.5232 & 0.1385 \\
$\hat{\mathrm{u}}_{\mathrm{t}-1}$ & -0.1942 & -1.0363 & 0.3086 \\
Constant & 0.0203 & 1.2744 & 0.2126 \\
Jarque Bera statistic & 0.2781 & \\
Durbin Watson statistic & 1.8164 & \\
Breusch Godfrey serial correlation LM test & 0.6268 & \\
(F statistic), including two lags ${ }^{\mathrm{a}}$ & & \\
Breusch-Pagan-Godfrey heteroskedasticity test & 0.5113 & \\
(F statistic) & 0.3238 & \\
R squared & 0.2539 & \\
Adjusted R squared & 4.6304 & \\
F statistic & -0.1538 & \\
$\Delta$ Ln P & 0.2273 & \\
$\Delta$ Ln GDP &
\end{tabular}

${ }^{\mathrm{a}}$ The results will be the same, if it includes more lags.

Table 5. Results of the dynamic model.

\begin{tabular}{cccc}
\hline Variables & Coefficient & t-statistic & Prob. \\
\hline Ln P & -0.1776 & -4.2945 & 0.0002 \\
Ln GDP & 0.3581 & 3.3025 & 0.0026 \\
Ln G ${ }_{\text {- } 1}$ & 0.5084 & 3.7460 & 0.0008 \\
Constant & -4.2121 & -3.1636 & \\
AR(1) & 0.2840 & \\
$\hat{\theta}_{1} / 1-\hat{\theta}_{3}$ & -0.3612 & \\
$\hat{\theta}_{2} / 1-\hat{\theta}_{3}$ & 0.7284 & \\
Jarque Bera statistic & 0.8288 & \\
Durbin Watson statistic & 2.1732 & \\
Breusch Godfrey serial correlation LM test & 1.1950 & \\
Breusch-Pagan-Godfric), including two lags ${ }^{\mathrm{a}}$ & 1.0896 & \\
(F statistic) & & \\
R squared & 0.9438 & \\
Adjusted R squared & 0.9358 &
\end{tabular}

${ }^{\mathrm{a}}$ The results will be the same, if it includes more lags. 
On the basis of the table, all the elasticities are low. The long run price and income elasticities of gasoline demand are 0.3612 and 0.7284 and the short run corresponding elasticities are -0.1776 and 0.3581 , respectively. The coefficients signs in this model are also accorded with the economic theories and the different econometric tests on the residual series fulfill the classical assumptions, nevertheless, autocorrelation problem will exist unless the regression is autoregressed. The regression fit goodness is evidenced by coefficients of determination and F statistic, as the previous models.

So the gasoline demand is price and income inelastic in the short run and long run.

Arranging the estimations of the three models in an increasing order, the short run, intermediate run and long run elasticities are achieved.

The intermediate run elasticities are estimated by correlating the static to the dynamic models. On one hand, the absolute value of the long run elasticities are more than the short run elasticities, as expected. On the other hand, the estimated elasticities in the static model range between the estimated long run and short run elasticities in the dynamic model. Hence, the static model estimates are interpreted as the intermediate price and income elasticities which are -0.1618 and 0.4636 , respectively [8].

Generally, the model implicates that the gasoline demand is inelastic with respect to price and income in the intermediate run.

\section{Discussion}

Table 6 represents the estimated elasticities through three different intervals, short run, intermediate run, and long run, as well as the adjustment velocity.

Regarding the table, although the short run price elasticity of the dynamic model is, surprisingly, more than that of the intermediate run, the estimates are broadly similar to the previous studies from two perspectives. Firstly, the price elasticities are less than the income elasticities [8]. Secondly, the price elasticities range in the most frequent groups of the classified elasticities by Dahl (2012) and Espey (1998), and the income elasticities in the second most [7] [9].

Not only the elasticities are low but also the adjustment velocity is slow. While all the signs of the elasticities are consistent with the economic theories, they are less than one in absolute value, meaning inelasticity over the three courses. The adjustment velocity is slow, at -0.19 , impling $19 \%$ of the gasoline consumption adjustment occurs during the first year. So disequilibrium lasts more than five years to reach long run equilibrium.

Consequently, the gasoline demand responds to the price and income changes slightly and slowly, relatively the same result as the previous studies.

\section{Conclusions}

The gasoline demand responds to price and income changes slightly and slowly in Iran during 1976-2010.

The gasoline demand is price and income inelastic in all the three intervals which characterizes gasoline as a necessary good with no close substitutes. Not only is the response magnitude of the gasoline consumption to price and income small but also the response speed is slow because the adjustment velocity is low. So price policy reduces the gasoline consumption ineffectively with a long delay. Even more, the price policy may be dominated by income rise in Iran as a developing country.

Increasing effect of income growth can overtake the decreasing effect of the price policy. The economy of Iran, on one hand, is expected to grow because developing economies are less than their potential level. The in-

\section{Table 6. Estimated elasticities through the intervals, using the static and dynamic models in brief.}

\begin{tabular}{|c|c|c|c|c|}
\hline \multirow{2}{*}{ Table Head } & \multicolumn{2}{|c|}{ Short run } & \multirow{2}{*}{ Intermediate run } & \multirow{2}{*}{ Long run } \\
\hline & ECM & Dynamic model & & \\
\hline Price elasticity & -0.1538 & $-0.1776^{\mathrm{a}}$ & -0.1618 & -0.3612 \\
\hline Income elasticity & 0.2273 & 0.3581 & 0.4636 & 0.7284 \\
\hline Adjustment velocity & -0.1942 & & & \\
\hline
\end{tabular}

${ }^{\mathrm{a}}$ Unexpected absolute value which is more than the intermediate run absolute value 
come elasticity of gasoline demand, on the other hand, is more than the price elasticity. Therefore, other alternatives, besides the price policy, should be developed to reduce the negative consequences of gasoline consumption, for example, supplying more environmentally friendly substitutes, more reliable public transportation systems, and setting higher environmental standards for industries, especially for car factories.

As a future study, estimating the elasticities of these factors can guide the governors and policy makers to pursue the most efficient policies.

\section{References}

[1] Rao, B.B. and Rao, G. (2009) Cointegration and the Demand for Gasoline. Energy Policy, 37, 3978-3983. http://dx.doi.org/10.1016/j.enpol.2009.04.046

[2] Sa'ad, S. (2009) An Empirical Analysis of Petroleum Demand for Indonesia: An Application of the Cointegration Approach. Energy Policy, 37, 4391-4396. http://dx.doi.org/10.1016/j.enpol.2009.05.058

[3] Bhattacharyya, S.C. and Blake, A. (2009) Domestic Demand for Petroleum Products in MENA Countries. Energy Policy, 37, 1552-1560. http://dx.doi.org/10.1016/j.enpol.2008.12.028

[4] Central Bank of the Islamic Republic of Iran (2014) Economic Time Series Database, Economic Research and Policy Department. http://tsd.cbi.ir/

[5] Ahmadian, M., Chitnis, M. and Hunt, L.C. (2007) Gasoline Demand, Pricing Policy and Social Welfare in Iran. SEEDS, 117, 1-25.

[6] Jafari, H.H. and Baratimalayeri, A. (2008) The Crisis of Gasoline Consumption in the Iran's Transportation Sector. Energy Policy, 36, 2536-2543. http://dx.doi.org/10.1016/j.enpol.2008.03.014

[7] Dahl, C.A. (2012) Measuring Global Gasoline and Diesel Price and Income Elasticities. Energy Policy, 41, 2-13. http://dx.doi.org/10.1016/j.enpol.2010.11.055

[8] Dahl, C. and Sterner, T. (1991) Analysing Gasoline Demand Elasticities: A Survey. Energy Economics, 13, $203-210$. http://dx.doi.org/10.1016/0140-9883(91)90021-Q

[9] Espey, M. (1998) Gasoline Demand Revisited: An International Meta-Analysis of Elasticities. Energy Economics, 20, 273-295. http://dx.doi.org/10.1016/S0140-9883(97)00013-3

[10] Baranzini, A. and Weber, S. (2013) Elasticities of Gasoline Demand in Switzerland. Energy Policy, 63, 674-680. http://dx.doi.org/10.1016/j.enpol.2013.08.084

[11] Wadud, Z., Graham, D.J. and Noland, R.B. (2009) A Cointegration Analysis of Gasoline Demand in the United States. Applied Economics, 41, 3327-3336. http://dx.doi.org/10.1080/00036840701477306

[12] Sene, S.O. (2012) Estimating the Demand for Gasoline in Developing Countries: Senegal. Energy Economics, 34, 189194. http://dx.doi.org/10.1016/j.eneco.2011.04.014

[13] Ramanathan, R. (1999) Short- and Long-Run Elasticities of Gasoline Demand in India: An Empirical Analysis Using Cointegration Techniques. Energy Economics, 21, 321-330. http://dx.doi.org/10.1016/S0140-9883(99)00011-0

[14] Akinboade, O.A., Ziramba, E. and Kumo, W.L. (2008) The Demand for Gasoline in South Africa: An Empirical Analysis Using Co-Integration Technique. Energy Economics, 30, 3222-3229. http://dx.doi.org/10.1016/j.eneco.2008.05.002

[15] Eltony, M.N. and Al-Mtairi, N.H. (1995) Demand for Gasoline in Kuwait: An Empirical Analysis Using Cointegration Techniques. Energy Economics, 17, 249-253. http://dx.doi.org/10.1016/0140-9883(95)00006-G

[16] Alves, D.C.O. and Bueno, R.D. (2003) Short-Run, Long-Run and Cross Elasticities of Gasoline Demand in Brazil. Energy Economics, 25, 191-199. http://dx.doi.org/10.1016/S0140-9883(02)00108-1

[17] Gujarati, D.N. (2004) Basic Econometrics. 4th Edition, MC-Graw-Hill, Classical Normal Linear Regression Model (CNLMR), Boston, Massachussets, 107-118.

[18] Engel, R.F. and Granger, C.W.J. (1987) Co-Intergration and Error Correction: Representation, Estimation, and Testing. Econometrica, 55, 251-276. http://dx.doi.org/10.2307/1913236

[19] National Iranian Oil Refining and Distribution Company (2014) Statistics Yearbook. Chapter 11 (in Persian). http://niordc.ir/uploads/fasle11.pdf

[20] Taylor, B.N. and Thompson, A. (2008) The International System of Units (IS), National Institute of Standards and Technology. US Department of Commerce, 37. 


\section{Appendices}

Apendix 1. The data which have been derived from the Economic Research and Policy Department of Iran ${ }^{\mathrm{a}}$.

\begin{tabular}{|c|c|c|c|c|}
\hline \multirow[t]{2}{*}{$\begin{array}{c}\text { Year } \\
\text { (based on Persian calendar) }\end{array}$} & $\begin{array}{l}\text { Price indices } \\
\text { Consumer Price } \\
\text { Index (CPI) } \\
(1383=100) \nabla\end{array}$ & $\begin{array}{c}\text { Energy Sector }>\text { Oil } \\
\text { Consumption of } \\
\text { Oil Products } \boldsymbol{\nabla}\end{array}$ & $\begin{array}{l}\text { Human resource and } \\
\text { Employment }>\text { Population } \\
\text { and Employment } \nabla\end{array}$ & $\begin{array}{c}\text { National Accounts } \\
\text { Gross National Product } \\
\text { and Income by Economic } \\
\text { Sectors } \\
\text { (at current prices) } \nabla\end{array}$ \\
\hline & General Index & $\begin{array}{c}\text { Gasoline (thousand barrels } \\
\text { per day) }\end{array}$ & $\begin{array}{l}\text { Total Population } \\
\text { (thousand persons) }\end{array}$ & $\begin{array}{l}\text { Gross domestic product } \\
\text { (at basic price) } \\
\text { (billion Rials) }\end{array}$ \\
\hline 1355 & 0.7 & 68 & 33,709 & 4391 \\
\hline 1356 & 0.9 & 79.7 & 35,025 & 5111 \\
\hline 1357 & 1 & 87.7 & 36,393 & 4987 \\
\hline 1358 & 1.1 & 98 & 37,814 & 6068 \\
\hline 1359 & 1.3 & 82.6 & 39,291 & 6299 \\
\hline 1360 & 1.6 & 76.3 & 40,826 & 7656 \\
\hline 1361 & 1.9 & 78.3 & 42,420 & 10,078 \\
\hline 1362 & 2.2 & 102.4 & 44,077 & 12,438 \\
\hline 1363 & 2.4 & 113.9 & 45,798 & 13,559 \\
\hline 1364 & 2.6 & 123.9 & 47,587 & 14,423 \\
\hline 1365 & 3.2 & 116.2 & 49,445 & 14,661 \\
\hline 1366 & 4.1 & 121.3 & 50,662 & 17,924 \\
\hline 1367 & 5.3 & 128.5 & 51,909 & 20,200 \\
\hline 1368 & 6.2 & 153.3 & 53,187 & 25,079 \\
\hline 1369 & 6.8 & 145.6 & 54,496 & 34,506 \\
\hline 1370 & 8.2 & 150.8 & 55,837 & 48,428 \\
\hline 1371 & 10.2 & 169 & 56,656 & 64,502 \\
\hline 1372 & 12.5 & 184.9 & 57,488 & 100,124 \\
\hline 1373 & 16.9 & 197 & 58,331 & 131,771 \\
\hline 1374 & 25.2 & 194 & 59,187 & 188,184 \\
\hline 1375 & 31.1 & 201 & 60,055 & 248,972 \\
\hline 1376 & 36.4 & 220 & 61,070 & 291,769 \\
\hline 1377 & 43 & 212 & 62,103 & 328,522 \\
\hline 1378 & 51.7 & 212 & 63,152 & 434,385 \\
\hline 1379 & 58.2 & 202 & 64,219 & 576,493 \\
\hline 1380 & 64.8 & 226 & 65,301 & 664,620 \\
\hline 1381 & 75.1 & 237 & 66,300 & 913,835 \\
\hline 1382 & 86.8 & 276 & 67,315 & $1,124,073$ \\
\hline 1383 & 100 & 335 & 68,345 & $1,455,690$ \\
\hline 1384 & 110.4 & 373 & 69,390 & $1,854,711.3$ \\
\hline 1385 & 123.5 & 422 & 70,496 & 2,260,529.6 \\
\hline 1386 & 146.2 & 362.7 & 71,532 & $2,861,974$ \\
\hline 1387 & 183.3 & 413 & 72,584 & 3,378,724.1 \\
\hline 1388 & 203 & 402.3 & 73,651 & 3,562,289.4 \\
\hline 1389 & 228.2 & 331.4 & 74,733 & $4,304,264.3$ \\
\hline
\end{tabular}

${ }^{\mathrm{a}} \mathrm{A}$ department in the Central Bank of the Islamic Republic of Iran [4]. 
Appendix 2. Gasoline: Current price in Iran [19].

\begin{tabular}{|c|c|}
\hline Year & Gasoline: current price \\
\hline 1976 & 6 \\
\hline 1977 & 8 \\
\hline 1978 & 10 \\
\hline 1979 & 10 \\
\hline 1980 & 30 \\
\hline 1981 & 30 \\
\hline 1982 & 30 \\
\hline 1983 & 30 \\
\hline 1984 & 30 \\
\hline 1985 & 30 \\
\hline 1986 & 30 \\
\hline 1987 & 30 \\
\hline 1988 & 30 \\
\hline 1989 & 30 \\
\hline 1990 & 50 \\
\hline 1991 & 50 \\
\hline 1992 & 50 \\
\hline 1993 & 50 \\
\hline 1994 & 50 \\
\hline 1995 & 100 \\
\hline 1996 & 130 \\
\hline 1997 & 160 \\
\hline 1998 & 200 \\
\hline 1999 & 350 \\
\hline 2000 & 385 \\
\hline 2001 & 450 \\
\hline 2002 & 500 \\
\hline 2003 & 650 \\
\hline 2004 & 800 \\
\hline 2005 & 800 \\
\hline 2006 & 1000 \\
\hline 2007 & 1000 \\
\hline 2008 & 1000 \\
\hline 2009 & 1000 \\
\hline 2010 & 4000 \\
\hline
\end{tabular}


Appendix 3. A.D calendar years versus Persian calendar years.

\begin{tabular}{|c|c|}
\hline A.D Calendar & Persian Calendar \\
\hline 1976 & 1355 \\
\hline 1977 & 1356 \\
\hline 1978 & 1357 \\
\hline 1979 & 1358 \\
\hline 1980 & 1359 \\
\hline 1981 & 1360 \\
\hline 1982 & 1361 \\
\hline 1983 & 1362 \\
\hline 1984 & 1363 \\
\hline 1985 & 1364 \\
\hline 1986 & 1365 \\
\hline 1987 & 1366 \\
\hline 1988 & 1367 \\
\hline 1989 & 1368 \\
\hline 1990 & 1369 \\
\hline 1991 & 1370 \\
\hline 1992 & 1371 \\
\hline 1993 & 1372 \\
\hline 1994 & 1373 \\
\hline 1995 & 1374 \\
\hline 1996 & 1375 \\
\hline 1997 & 1376 \\
\hline 1998 & 1377 \\
\hline 1999 & 1378 \\
\hline 2000 & 1379 \\
\hline 2001 & 1380 \\
\hline 2002 & 1381 \\
\hline 2003 & 1382 \\
\hline 2004 & 1383 \\
\hline 2005 & 1384 \\
\hline 2006 & 1385 \\
\hline 2007 & 1386 \\
\hline 2008 & 1387 \\
\hline 2009 & 1388 \\
\hline 2010 & 1389 \\
\hline
\end{tabular}


Scientific Research Publishing (SCIRP) is one of the largest Open Access journal publishers. It is currently publishing more than 200 open access, online, peer-reviewed journals covering a wide range of academic disciplines. SCIRP serves the worldwide academic communities and contributes to the progress and application of science with its publication.

Other selected journals from SCIRP are listed as below. Submit your manuscript to us via either submit@scirp.org or Online Submission Portal.
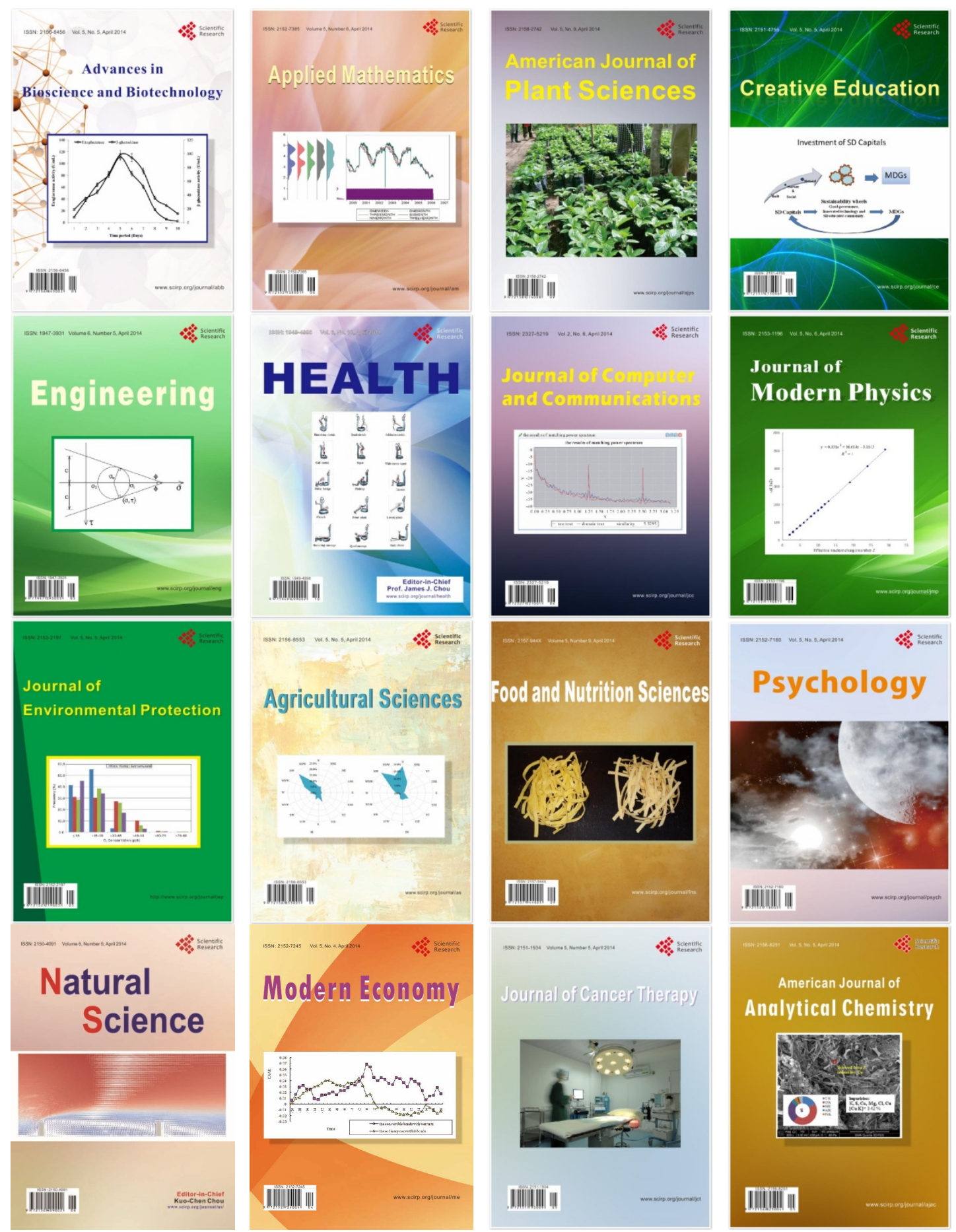